\title{
Penilaian Terhadap Prestasi Pelajar dan Pengurusan Program Praktikum Universiti Utara Malaysia
}

\author{
*LIM KHONG CHIU \\ NOR IDAYU MAHAT \\ SHAHIZAN HASSAN \\ ABDUL RAZAK CHIK \\ MOHD AZLAN YAHYA \\ Universiti Utara Malaysia \\ *(Ikc@uum.edu.my)
}

\begin{abstract}
ABSTRAK
Kajian ini memberi fokus kepada maklum balas organisasi terhadap prestasi pelajar dan pengurusan program praktikum, Universiti Utara Malaysia (UUM). Sebanyak 438 buah organisasi daripada pelbagai latar belakang industri telah mengambil bahagian dalam kajian ini. Kutipan data dilaksanakan dengan menggunakan soal selidik yang merangkumi lima komponen utama iaitu; profil responden dan organisasi, prestasi pelajar, prestasi pengurusan program praktikum, perbandingan prestasi dengan institusi pengajian lain dan kesesuaian program praktikum. Secara umumnya, kajian ini mendapati organisasi terlibat berpuas hati dengan prestasi pelajar UUM dalam persiapan mereka menempuh alam pekerjaan sebenar. Sistem pengurusan praktikum yang dilaksanakan di Pusat Jaringan Universiti-Industri (UIL) juga dianggap tersusun dan efisien. Di samping itu, hasil kajian ini juga menunjukkan tidak terdapat perbezaan yang ketara antara prestasi pelajar UUM dengan pelajar dari universiti yang lain. Beberapa cadangan penambahbaikan terhadap kemahiran pelajar dan sistem pengurusan praktikum di UUM telah dikenal pasti.
\end{abstract}

\section{ABSTRACT}

Purpose - The main focus of this study is to obtain the feedback from organisations with regards to the performance of UUM's practicum students and practicum programme management. 
Method - A total of 438 organisations from different industrial backgrounds participated in this study. Data collection was carried out by using a questionnaire which consists of five main components measuring respondents' profile, students' performance, practicum programme management, performances comparison with other universities, and the suitability of the practicum programme.

Findings - The feedback obtaimed indicates that the participating organisations are satisfied with the performance of UUM students in preparing themselves for real work environment. The practicum management system that is practised by Centre for UniversityIndustry Link (UIL) is also considered well organised and efficient. In addition, this study shows that there is no obvious difference between UUM students' performance and students of other universities.

Value - Several suggestions to improve students' skills and practicum management system are identified. Information gathered can provide important insights from the perspective of organizations which can be valuable in improving the industrial training/practicum programmes as well as the overall academic programmes for future professionals and managers.

Keywords: Industrial training/practicum, Programme management, Student's performance, Organization, Feedback

\section{PENGENALAN}

Program praktikum telah lama diakui sebagai satu kaedah yang penting untuk persediaan pelajar menghadapi kerjaya dalam profesion masing-masing (Seigler, Gentry, \& Edwards, 1979; Weinberg, 1986). Program ini bertujuan memberi pendedahan kepada para pelajar untuk memahami hal-hal yang berkaitan dengan alam pekerjaan yang sebenar sebelum mereka menamatkan pengajian mengikut bidang pengkhususan yang dijurusi. Di samping itu, para pelajar juga berpeluang untuk menerapkan kefahaman teori dan amali yang telah dipelajari melalui tugasan yang dipertanggungjawabkan semasa di organisasi/industri. Justeru, program praktikum pelajar sewajarnya diberikan perhatian yang serius oleh institusi-institusi pengajian tinggi awam mahupun swasta kerana latihan sedemikian membolehkan para pelajar mendapat pendedahan dan pengalaman 
bekerja yang amat bernilai. Bagi tujuan itu, institusi pengajian tinggi awam dan swasta (IPTA/IPTS) hendaklah merancang, meneliti, dan mengkaji program praktikum masing-masing supaya para pelajar akan mendapat manfaat yang bermakna daripada latihan tersebut. Maka mutu pelajar yang akan dihasilkan oleh institusi pengajian tinggi (IPT) kelak bukan sahaja tinggi daripada segi inteleknya tetapi juga memiliki kemahiran serta keperibadian yang terpuji. Para pelajar juga akan menjadi lebih kompetitif, berdaya maju, dan seterusnya berpotensi untuk meningkatkan lakuan kerja (employability) setelah tamat pengajian.

Kepentingan program praktikum dapat dilihat dalam dua perspektif berbeza iaitu pelajar dan institusi pengajian tinggi. Daripada perspektif pelajar, program ini cukup bermakna untuk memberi pendedahan kepada mereka tentang persekitaran pekerjaan sebenar. Hal ini dijelaskan oleh Weinberg (1986) dan Mihail (2006) bahawa praktikum bukan sahaja dapat mengajar pelajar bagaimana menghubungkan antara realiti dan konsep-konsep dan teori-teori yang dipelajari semasa di universiti tetapi ia juga dapat memberi pendedahan tentang persekitaran pekerjaan yang sebenar. Daripada perspektif institusi pengajian tinggi, praktikum merupakan antara mekanisme yang baik untuk digunakan bagi menilai keberkesanan sesuatu program pengajian. Penggunaan kaedah ini dapat memberi maklum balas yang berguna kepada institusi berkenaan untuk tujuan penambahbaikan terhadap kurikulum dan kaedah pengajaran (Gardner, 1999; Beck \& Kosnick, 2002). Di samping itu, program praktikum juga dapat bertindak sebagai mekanisme yang berkesan untuk menjalin hubungan yang baik antara institut pengajian tinggi dan industri ke arah pembangunan sistem pendidikan tinggi yang lebih efektif (Zhao \& Harris, 2004).

Di samping itu, program praktikum juga boleh dijadikan sebagai satu strategi kerajaan untuk mengatasi masalah pengangguran dalam kalangan siswazah yang semakin meningkat dari semasa ke semasa. Apabila pelajar menunjukkan prestasi yang baik semasa menjalani program praktikum di industri, keadaan ini boleh mendorong majikan untuk terus menyerap pelajar berkenaan sebagai pekerja di organisasi mereka (Mustapa Mahamed, 2007). Justeru, di kebanyakan IPT program praktikum telah mendapat pengiktirafan sebagai satu daripada komponen dalam kurikulum program pengajian di peringkat ijazah pertama. Bagi sesetengah program dalam bidang sains dan teknikal seperti kedoktoran, kejuruteraan, dan bidang sains sosial seperti kaunseling, perakaunan, 
dan pendidikan, praktikum merupakan komponen yang wajib dan diberikan sejumlah kredit tertentu. Pelajar dikehendaki menjalani praktikum dan mesti lulus bagi membolehkan mereka menamatkan pengajian masing-masing dengan jayanya. Sehubungan itu, fokus utama dalam artikel ini adalah untuk meninjau tentang prestasi pelajar dan pengurusan program praktikum dalam konteks Universiti Utara Malaysia.

\section{PENGURUSAN PROGRAM PRAKTIKUM DI UUM}

Program praktikum atau latihan industri merupakan komponen utama dalam kebanyakan struktur program pengajian di peringkat Sarjana Muda di institusi pengajian tinggi di Malaysia. Malahan program seumpama ini telah menjadi komponen wajib sebagai syarat pengijazahan bagi kebanyakan program pengajian Sarjana Muda di IPT awam. Dalam konteks di UUM, program ini dikenali sebagai praktikum yang membawa maksud menjalani proses latihan industri dalam organisasi di luar suasana kelas formal universiti yang bertujuan membentuk potensi-potensi pelajar untuk pasaran kerja pada masa depan. Sehubungan itu, semua program praktikum UUM adalah diuruskan sepenuhnya oleh Pusat Praktikum (PPR), kini dikenali sebagai Pusat Jaringan Universiti-Industri (UIL).

UIL adalah pusat yang bertanggungjawab dalam urusan mencari tempat yang sesuai sama ada di organisasi swasta, badan berkanun dan kerajaan untuk menempatkan para pelajar menjalani praktikum. Dalam pada itu, Sistem Maklumat Praktikum (SISPR) telah digunakan khususnya dalam menguruskan proses penempatan, penyeliaan dan penilaian pelajar di organisasi-organisasi yang terpilih. Sistem Penempatan Pelajar Praktikum Secara Atas Talian (OPSP) turut digunakan untuk membantu dalam pengurusan penempatan pelajar di industri/organisasi. Sistem ini dibangunkan berasaskan kepada pendekatan penyelidikan. Objektif OPSP adalah untuk membangunkan sebuah sistem berkomputer di dalam persekitaran extranet bagi membantu proses penempatan pelajar praktikum di pelbagai organisasi di seluruh Malaysia (Shahizan Hassan, Mohd Azlan Yahya, Abdul Razak Chik, \& Wan Husin Wan Ishak, 2006).

Di samping itu, penyeliaan praktikum diadakan bertujuan memantau prestasi pelajar serta mendapat maklum balas daripada organisasi. Penyeliaan dilakukan oleh staf akademik yang dilantik mengikut setiap program pengajian di kolej masing-masing. 
Sehubungan itu, penyeliaan secara bersama dengan pihak organisasi telah dilaksanakan sepanjang tempoh praktikum. Dalam tempoh praktikum selama empat atau enam bulan, penyelia juga dikehendaki mengadakan lawatan ke organisasi sekurang-sekurangnya sekali untuk memantau perkembangan pelajar dan mendapatkan maklum balas daripada pihak organisasi.

Proses penilaian praktikum pelajar pula melibatkan penyelia UUM dan organisasi praktikum pelajar. Sehubungan itu, penilaian praktikum pelajar ditetapkan oleh Jawatankuasa Program Praktikum di kolej selepas diluluskan oleh Senat bagi tujuan pelaksanaan. Pihak Jawatankuasa akan memberikan garis panduan penilaian mengikut kesesuaian program pengajian. Secara umumnya, terdapat tiga komponen utama yang digunakan sebagai kriteria dalam penilaian praktikum. Komponen-komponen tersebut ialah laporan tugasan, laporan organisasi dan laporan penyelia UUM. Walau bagaimanapun, terdapat juga program pengajian tertentu yang menetapkan kriteria tambahan dalam penilaian praktikum seperti menghadiri bengkel dan persembahan hasil projek yang telah disempurnakan.

\section{TINJAUAN LITERATUR}

Mengikut Gardner (1999), kepentingan peranan praktikum atau latihan industri yang diperoleh melalui pengalaman secara ' $h a n d s$ on' merupakan cara yang asas untuk menajamkan kemahirankemahiran pelajar di samping mendapatkan celik akal yang baru tentang kerjaya dalam profesion masing-masing. Begitu juga halnya apabila diteliti mengenai peranan penting yang dimainkan melalui program praktikum dalam perkembangan profesional, pelbagai penerbitan tentang kajian-kajian terdahulu yang berkaitan telah mengenal pasti beberapa isu utama yang berkisar kepada aspek teori reka bentuk dan pengalaman dalam pelaksanaan praktikum (Misalnya, Dras \& Miller, 2002; Lloyd \& Briston, 2006; Ovens, 2004), pendedahan mengenai persepsi bakal pekerja/ pelatih (intern) dan penyelia tentang sesuatu program praktikum yang baik (Misalnya, Beck \& Kosnick, 2002; Henry, Rehwaldt, Vineyard, 2001; Kantha Kumar Ramasamy, 1997), perubahan bakal pekerja/ pelatih (intern) semasa program praktikum (Misalnya, Barney \& Pleban, 2006; Girard, Hickam, Gordon, \& Robison, 1991; Griffith \& Wilson, 2003), tekanan kerja semasa sesuatu program praktikum (Misalnya, Murray-Harvey, 2001; Tyssen, Vaglum, Gronvold 
\& Ekeberg, 2005), penggunaan IT dalam program praktikum (Misalnya, Almahdi Mohammad Almahdi Ahmed, 2006; Doering, Johnson, \& Dexter, 2003; Graf \& Stebnicki, 2002; Shahizan Hassan, Mohd Azlan Yahya, Abdul Razak Chik, \& Wan Hussein Wan Ishak, 2006), dan pelbagai isu lain dalam latihan praktikum (Misalnya, Basri Rashid, 2001; Lee, 2001).

Lloyd dan Briston (2006) menjelaskan dalam kajiannya bahawa menjalankan praktikum secara klinikal di sesebuah komuniti adalah bertujuan memudah cara sistem pementoran dan kerjasama antara pelajar. Dalam pelaksanaannya, para pelajar prasiswazah dan pascasiswazah telah diagihkan melalui sistem mentor-mentee. Pelajar-pelajar bekerjasama dengan pihak fakulti dan staf klinikalnya untuk membangunkan rangkaian pementoran dan latihan kolaboratif secara efektif untuk tujuan praktikum.

Beck dan Kosnick (2002) pula mengkaji persepsi guru-guru pelatih terhadap komponen-komponen dalam program praktikum yang baik. Mereka mendapati bahawa guru-guru pelatih menghargai unsur-unsur seperti sokongan yang bersifat emosi daripada guru pendamping, keluwesan dalam kaedah dan kandungan pengajaran, maklum balas daripada guru pendamping, kecekapan pendekatan yang digunakan terhadap pengajaran dan pembelajaran daripada guru pendamping, dan beban kerja yang munasabah semasa praktikum.

Kajian yang berkaitan oleh Kantha Kumar Ramasamy (1997) juga mendapati guru pelatih mempunyai persepsi yang positif terhadap kualiti bimbingan yang diberi oleh pensyarah pembimbing mereka. Walau bagaimanapun, keputusan kajian ini menunjukkan bahawa kesediaan mereka untuk menghadapi praktikum dari segi kemahiran masih kurang mencukupi. Tetapi hampir semua daripada mereka yakin bahawa latihan praktikum telah membantu mereka menguasai kemahiran-kemahiran mengajar. Oleh itu, kajian ini telah berjaya memperoleh beberapa indikator untuk mengkaji semula strategi pelaksanaan praktikum serta strategi persediaan guru pelatih untuk menghadapi kurikulum di sekolah.

Di samping itu, terdapat dalam kajian-kajian awal membuktikan bahawa bakal pekerja/ pelatih menunjukkan perubahan sikap semasa praktikum. Malahan perolehan nilai-nilai positif hasil daripada program praktikum telah banyak didokumentasikan dalam kajian-kajian lampau yang berkaitan (Kok, 2000). Girard, Hickam, Gordon dan Robison (1991) dalam kajian mereka menjelaskan bahawa mood (misalnya, kebimbangan, perasaan kecekapan, 
ketidakpuasan dan kemurungan) berubah dalam kalangan doktor pelatih dari semasa ke semasa sepanjang program internship.

Dalam pada itu, penggunaan teknologi maklumat (IT) dalam program praktikum juga telah mendapat perhatian para penyelidik. Hal ini termasuk kajian-kajian yang memfokuskan ke atas, 'web-based asynchronous discussion' (Doering et al, 2003), 'email communication' (Graf \& Stebnicki, 2002), penggunaan “videoconferencing' (Panos et al., 2002), penempatan secara atas talian (Shahizan et al., 2006), dan penempatan pelajar menggunakan teknik 'data mining' (Almahdi Mohammad Almahdi Ahmed, 2006).

Hasil kajian oleh Shahizan et al. (2006), hasil kajian mereka dapat menyumbang kepada UIL dalam proses menguruskan penempatan pelajar praktikum. Hal ini kerana proses pemadanan pelajar dengan organisasi dilakukan oleh penyelaras dan staf UIL secara manual dengan mengambil kira kriteria yang ditetapkan oleh organisasi dan pemilihan pelajar. Berikutan dengan itu, kerap kali berlaku pemadanan yang tidak tepat hasil daripada berurusan dengan bilangan pelajar yang ramai. Oleh itu, kejayaan membangunkan satu sistem yang dinamakan Sistem Penempatan Pelajar Secara Atas Talian (OPSP) oleh Shahizan et al. (2006) telah dapat membantu UIL memperbaiki sebahagian kelemahannya dalam mengurus dan memantau program praktikum di UUM. Hasil penggunaan sistem OPSP dapat mengurangkan kos operasi pengurusan penempatan, meningkatkan hasil kerja staf di UIL, meningkatkan kepuasan dari segi hubungan dan komunikasi antara UIL dengan organisasi.

Dalam konteks kajian terhadap keberkesanan kurikulum program praktikum pula, Ferguson (1991) mendapati bahawa program praktikum dapat memantapkan kurikulum pengajaran dan aktiviti-aktiviti antara universiti dan industri. Kedua-dua faktor ini merupakan faktor penting yang menimbulkan masalah punca, serta jurang yang terbentuk antara harapan industri dan pendidikan universiti. Hal ini turut disokong dalam kajian-kajian lepas (Lawrence, 1991; Nash, 1992) yang menunjukkan bahawa program praktikum adalah relevan dan membentuk komponen yang sangat penting dalam menilai keberkesanan kurikulum.

Seterusnya, Rosnita (2005) dalam kajiannya telah memfokuskan tentang penilaian organisasi terhadap pelajar UUM yang menjalankan latihan industri pada sesi 2004. Penilaian organisasi dilakukan berasaskan persepsi terhadap beberapa aspek tentang pelajar seperti disiplin, keupayaan menganalisis, kepimpinan, rupa diri dan komunikasi. Penyelidik telah merujuk 
kepada 30 borang laporan sulit penyelia organisasi yang dipilih secara rambang. Sehubung itu, sebanyak 15 borang pelajar dari jurusan Pembangunan Awam dan Undang-undang dan 15 borang pelajar dari jurusan Perakaunan telah dipilih untuk tujuan kajiannya. Hasil kajiannya membuktikan bahawa pada keseluruhannya persepsi organisasi terhadap aspek-aspek yang dikaji adalah pada tahap yang baik.

Begitu juga halnya dengan dapatan kajian Mohd Salleh Hj Din et al. (1995) menunjukkan bahawa prestasi kerja siswazah UUM didapati memuaskan organisasi. Walau bagaimanapun, aspek penghasilan kerja diamati lebih baik prestasinya berbanding aspek-aspek kualiti diri, pengetahuan dan kemahiran. Di samping itu, daripada segi daya usaha dan pelaksanaan peraturan, majoriti siswazah berada pada tahap membanggakan. Keupayaan mereka melaksanakan peraturan dan arahan pentadbiran juga adalah pada tahap memuaskan.

Selain itu, Zhao dan Harris (2004) pula menyatakan bahawa latihan industri/praktikum adalah penting bagi tujuan penilaian yang berkesan terhadap kualiti sesuatu program pengajian. Kajian mereka mendapati bahawa program internship atau praktikum pada umumnya boleh memperkembangkan nilai yang positif terhadap pihak fakulti dan organisasi. Oleh itu, kajian ini menyarankan bahawa usaha perlu diadakan untuk mengekalkan hubungan antara institusi pengajian dan industri melalui program praktikum atau internship supaya dapat menyuburkan harapan, kemahiran baru dan pengetahuan terkini mengenai isu-isu yang dihadapi bersama.

Walaupun secara idealnya, program praktikum mampu menawarkan pelajar peluang-peluang untuk mengaplikasikan pengetahuan, kemahiran, menguji teori-teori, dan akhirnya mengubah suai kefahaman mereka, namun dalam melaksanakan program ini terdapat pelbagai kekangan dan masalah yang wujud. Menurut Pitts dan Miller (1990), kebanyakan masalah dan kekangan yang dihadapi semasa latihan praktikum adalah berpunca daripada pelbagai faktor, iaitu masalah yang dijana oleh pelajar sendiri hingga kepada masalah yang disebabkan oleh sistem yang sedia ada di sesebuah organisasi (Abdul Razak \& Ahmad Shukri, 2002). Hal ini selari dengan penemuan kajian-kajian lampau yang menunjukkan bahawa prestasi graduan, sama ada di sektor awam mahupun swasta berada pada tahap kemahiran yang rendah terutama dari segi komunikasi, kreativiti dan inisiatif (Berita Harian, 26 November 2006). 
Berkaitan dengan hal itu, Basri Rashid (2001) telah mengenal pasti dalam kajiannya tentang beberapa masalah yang dihadapi oleh pelajar program hospitaliti dan pelancongan dalam program praktikum. Antara masalah yang menimbulkan kesulitan kepada para pelajar menjalani latihan praktikum dengan berkesan adalah isu-isu yang berkaitan dengan kesukaran untuk menyesuaikan diri dengan persekitaran yang baru, amalan dan keperluan dalam tuntutan sesuatu agama, ketidakcekapan dalam berkomunikasi, organisasi mengambil kesempatan (exploitation) dan beban kerja yang tidak relevan, arahan dan maklumat yang tidak jelas, sara diri dan faedah sampingan, tiada kerjasama dan kurang keyakinan diri. Oleh itu, beliau menyarankan bahawa kedua-kedua pihak iaitu organisasi dan insititusi pendidikan hendaklah membina hubungan yang baik melalui penganjuran mesyuarat dan perbincangan dengan lebih kerap untuk memupuk persefahaman tentang keperluankeperluan dan jangkaan-jangkaan kedua-dua pihak demi mencapai situasi "menang-menang". Satu program latihan piawaian yang sesuai untuk kedua-dua pihak boleh direka bentuk dengan memberi tumpuan terhadap tugas dan tanggungjawab yang relevan dengan program pengajian pelajar. Hal ini penting kerana menurut beliau ada kemungkinan pelajar atau pelatih yang sama akan kembali untuk bekerja di industri atau organisasi berkenaan. Justeru, satu program latihan yang berkualiti pada umumnya akan menguntungkan industri/ organisasi kerana boleh menjimatkan masa dan kos latihan.

Selain itu, isu tentang program praktikum juga dapat dikaitkan dengan jangkaan-jangkaan dan pengalaman sebenar pelajar dalam mengikuti program praktikum. Lee (2001) dalam kajiannya melaporkan bahawa pelajar dalam jurusan hospitaliti mempunyai jangkaan tertentu iaitu dengan mengikuti program praktikum akan mendapat peluang untuk mereka mengamalkan pengetahuan, kemahiran dan sikap yang telah dipelajari di kolej atau universiti di samping peluang untuk mendapatkan kemanfaatan dan keseronokan. Namun demikian, dari segi realitinya, beberapa aspek dalam program praktikum tidak mencapai harapan dan pengalaman yang dijangkakan sehingga mengakibatkan perubahan ketara dalam tanggapan mereka terhadap industri.

Secara umumnya, hasil daripada sorotan kajian-kajian terdahulu yang berkaitan membuktikan bahawa program latihan industri/praktikum adalah penting untuk membekalkan pelajar dengan pengetahuan dan kemahiran amali mengikut bidang pengkhususan masing-masing. Di samping itu, hasil praktikum juga 
mampu untuk membantu para pelajar mempertingkat kemahiran insaniah. Oleh yang demikian, adalah wajar bagi IPT yang menguruskan program praktikum menilai dan mengkaji pengurusan program latihan industri/ praktikum pelajar masing-masing supaya kemanfaatan program tersebut dapat diperoleh dengan lebih berkesan.

\section{PERNYATAAN MASALAH}

Pengurusan praktikum merupakan satu tugas dan tanggungjawab yang mencabar bagi setiap universiti. Secara umumnya ia merangkumi tiga proses utama iaitu penempatan, penyeliaan dan penilaian pelajar. Dalam konteks penempatan pelajar, universiti sering menghadapi masalah untuk menempatkan pelajar di industri yang sesuai dengan bidang pengajian mereka. Manakala dalam aspek penyeliaan dan penilaian, isu yang sering dihadapi adalah berkaitan dengan keberkesanan mekanisme yang digunakan untuk tujuan menilai prestasi pelajar semasa menjalani praktikum. Begitu juga halnya dengan kurikulum praktikum yang dianggap sebagai tidak mampu menyetarakan antara keperluan industri dan pembelajaran semasa universiti. Justeru, ketidaksetaraan itu telah menimbulkan pelbagai tanggapan dalam kalangan majikan terhadap kebolehan dan kemahiran para pelajar di pasaran kerja. Tidak dapat dinafikan bahawa kejayaan program praktikum adalah bergantung kepada kecekapan dan keberkesanan sesebuah universiti mengurus program tersebut serta mempunyai kurikulum praktikum yang sejajar dengan keperluan industri. Oleh itu, bagi memastikan program ini dapat diuruskan dan ditadbirkan dengan cekap dan berkesan di samping mempunyai nilai tambah ke arah meningkatkan kebolehpasaran dalam kalangan pelajar, maka kajian yang berbentuk tinjauan dan maklum balas di IPT dan industri atau organisasi merupakan antara aktiviti penting yang perlu dilaksanakan.

Di samping itu, secara umumnya amalan pengurusan program praktikum yang dikendalikan oleh universiti di Malaysia adalah berbeza antara satu satu sama lain. Sebagai contoh, Universiti Utara Malaysia dan Universiti Malaya mengamalkan sistem pengurusan praktikum secara berpusat iaitu satu pusat khusus bertanggungjawab dalam menguruskan prosedur praktikum pelajar di industri. Selain itu, terdapat juga pendekatan yang tidak berpusat dilaksanakan setiap fakulti di universiti masing-masing menguruskan praktikum 
pelajar mereka seperti yang dilaksanakan di Universiti Kebangsaan Malaysia dan Universiti Putra Malaysia. Dengan wujudnya perbezaan itu telah menimbulkan kesukaran kepada pihak Kementerian Pengajian Tinggi untuk menghasilkan satu piawaian yang lebih selaras untuk diterima pakai terhadap program-program pengajian yang ditawarkan oleh semua universiti. Begitu juga halnya dengan pihak organisasi dan industri juga akan menghadapi masalah untuk menyediakan tempat bagi praktikum kepada pelajar-pelajar pada sesuatu sesi tertentu. Jika hal ini tidak ditangani dengan baik dan teratur, maka proses pengurusan praktikum di universiti akan menjadi semakin tidak terurus dan terselaras.

Sehingga kini kajian empirikal yang pernah diusahakan tentang aspek tersebut sama ada di peringkat universiti per se atau di peringkat IPTA/ IPTS keseluruhannya amat terbatas. Oleh itu, adalah wajar kajian yang berbentuk penerokaan (exploratory) dijalankan untuk mendapatkan maklumat awal bagi tujuan perancangan kajian yang lebih komprehensif untuk mencapai objektif-objektif yang berkaitan dengan pengurusan program praktikum. Justeru, kajian ini bertujuan mendapatkan maklum balas organisasi berkenaan dengan prestasi pelajar dan pengurusan program praktikum UUM. Maklum balas merupakan elemen yang penting dalam pengurusan strategik sesebuah organisasi kerana maklum balas boleh digunakan untuk membantu dalam menilai dan membuat penambahbaikan terhadap perancangan yang sedia ada.

\section{OBJEKTIF KAJIAN}

Berdasarkan permasalahan dan tujuan kajian, kajian ini telah menggariskan empat objektif seperti berikut:

1. Untuk menilai tahap prestasi pelajar UUM dalam aspek pengetahuan asas, kemahiran komunikasi, kemahiran praktikal, kepimpinan dan disiplin diri daripada perspektif organisasi.

2. Untuk menilai tahap prestasi UUM dalam mengurus program praktikum daripada perspektif organisasi.

3. Untuk menilai tahap prestasi pelajar UUM berbanding pelajar IPT lain daripada perspektif organisasi.

4. Untuk mengumpul cadangan-cadangan daripada organisasi bagi tujuan penambahbaikan prestasi pelajar dan pengurusan program praktikum UUM. 
Secara khususnya, kajian ini memberikan tumpuan untuk mendapatkan jawapan kepada persoalan-persoalan berikut:

1. Apakah maklum balas organisasi terhadap prestasi pelajar UUM semasa menjalani program praktikum?

2. Apakah maklum balas organisasi terhadap prestasi UUM dalam mengurus program praktikum?

3. Bagaimanakah prestasi pelajar UUM berbanding dengan pelajar IPT lain semasa menjalani program praktikum?

4. Apakah cadangan-cadangan daripada organisasi untuk meningkatkan prestasi pelajar dan pengurusan program praktikum UUM?

\section{KEPENTINGAN KAJIAN}

Hasil kajian ini dapat memberi input penting kepada UUM amnya dan UIL secara khususnya berhubung dengan proses penempatan, penyeliaan dan penilaian program untuk menambah baik program praktikum UUM di samping menyediakan sistem pengajaran dan pembelajaran yang bersesuaian dengan kehendak pasaran. Maklum balas yang diperoleh boleh digunakan untuk menilai kembali pelaksanaan kaedah pengajaran dan pembelajaran bagi melahirkan siswazah yang mempunyai kebolehpasaran yang tinggi untuk memenuhi keperluan industri. Kajian ini juga amat penting kepada UIL untuk meningkatkan jalinan hubungan dengan industri bagi memudahkan proses penempatan pelajar menjalani praktikum, di samping membuka ruang untuk perkongsian pengetahuan dan latihan sabatikal bagi kakitangan UUM. Seterusnya, hasil kajian ini penting bagi UIL untuk melaksanakan strategi penambahbaikan yang berterusan dalam menguruskan program praktikum dari semasa ke semasa.

\section{METODOLOGI}

\section{Populasi dan Sampel}

Semua organisasi yang terlibat dengan pengambilan pelajar praktikum UUM bagi sesi Disember 2006/2007 (sesi A062) telah dipilih untuk mengambil bahagian dalam kajian ini. Senarai organisasi yang menawarkan tempat praktikum ini diperoleh daripada pangkalan 
data Sistem Praktikum (SISPR) yang memperincikan latar belakang organisasi serta pegawai yang bertanggungjawab menyelia pelajar UUM di organisasi berkenaan.

Bagi organisasi yang memperuntukkan lebih daripada seorang pegawai penyelia, setiap pegawai ini akan dianggap sebagai satu entiti berbeza walaupun mereka adalah daripada organisasi yang sama. Hal ini disebabkan walaupun pelajar dinilai oleh pegawai yang berbeza ada kemungkinan pelajar berkenaan ditempatkan di unit atau bahagian yang berbeza antara satu sama lain.

Secara keseluruhannya, terdapat 712 buah organisasi yang menyediakan penempatan praktikum untuk pelajar UUM pada sesi A062. Daripada jumlah ini, 438 (61.5\%) daripadanya mengembalikan borang soal selidik maklum balas kepada UIL berkaitan dengan kajian yang dilaksanakan.

\section{Instrumen Kajian}

Kajian ini telah menggunakan soal selidik dalam proses memungut data bagi tujuan untuk menjawab soalan-soalan kajian. Tujuan utama instrumen kajian ini ialah untuk menilai prestasi pelajar dan pengurusan program praktikum UUM. Soal selidik digunakan kerana kaedah ini sesuai untuk memungut data yang melibatkan responden (organisasi) yang berselerak kedudukannya di seluruh negara di samping bertujuan mendapatkan maklum balas daripada seberapa banyak organisasi yang dikenal pasti mengambil bahagian dalam program praktikum (Sekaran, 2003).

\section{Pembentukan Soal Selidik}

Soal selidik yang dihasilkan terbahagi kepada lima bahagian iaitu profil responden organisasi, prestasi pelajar, prestasi pengurusan program latihan industri/ praktikum, perbandingan prestasi dengan institusi pengajian tinggi lain, dan kesesuaian program latihan industri/praktikum.

Bahagian I yang terdiri daripada profil responden mempunyai tujuh soalan pilihan pelbagai berkaitan maklumat profil organisasi seperti jenis industri, bilangan pekerja, dan sebagainya. Bahagian II soal selidik dikhususkan kepada maklumat tentang pencapaian pelajar di organisasi. Bahagian ini meliputi lima aspek utama iaitu, pengetahuan asas, kemahiran komunikasi, kemahiran amali, kepemimpinan, dan sikap. Bagi tujuan ini, skala Likert digunakan 
mengikut urutan seperti berikut: (1) Sangat tidak memuaskan, (2) Tidak memuaskan, (3) Memuaskan, (4) Sangat memuaskan, dan (5) Cemerlang. Bahagian III soal selidik bertujuan menilai prestasi pengurusan program praktikum dengan meliputi tiga aspek utama iaitu daripada segi penempatan pelajar, penyeliaan pelajar, dan penilaian pelajar. Skala Likert seperti bahagian II turut digunakan di dalam bahagian ini. Bahagian IV pula mempunyai tiga soalan subjektif untuk menilai prestasi pelajar dan pengurusan program praktikum UUM berbanding dengan universiti-universiti lain. Bahagian akhir soal selidik mengandungi lima soalan subjektif yang meneroka pandangan organisasi/ majikan mengenai kesesuaian program latihan industri pelajar.

Proses pembinaan soal selidik ini adalah berasaskan kepada dua sumber utama iaitu soroton karya terdahulu (misalnya, Abdul Razak Manaf \& Ahmad Shukri, 2002; Beard, 2007; Mohd Salleh et. al, 1995; Mohammad Hasnan \& Ang Chooi Leng, 2002; Rosnita Ahmad, 2005) dan maklum balas daripada organisasi dari semasa ke semasa mengikut kesesuaian tujuan kajian ini (Pusat Praktikum, 2005).

\section{Kesahan Muka dan Kandungan Instrumen}

Sebelum soal selidik dihantar kepada organisasi, proses kesahan muka dan kandungannya telah dibuat. Pengujian kesahan muka dan kandungan ini dilakukan oleh pakar bidang yang terdiri daripada empat orang pegawai pengurusan tertinggi UIL, seorang pegawai tertinggi UUM, dan dua orang wakil fakulti. Sebanyak tiga perbincangan telah diadakan untuk tujuan ini dan hasilnya telah digunakan untuk penambaikan soal selidik.

\section{Tata Cara Pungut Data}

Dua kaedah pungutan data telah digunakan dalam kajian ini, pertama melalui pensyarah pelawat dan kedua secara pos. Setiap pensyarah pelawat telah dibekalkan dengan beberapa borang soal selidik yang berkaitan dengan kajian ini untuk tujuan mempermudah dan mempercepat proses pengedaran borang soal selidik kepada organisasi. Soal selidik juga telah dihantar melalui pos kepada organisasi yang tidak dilawati oleh pensyarah semasa kajian ini dijalankan. Surat peringatan kepada semua organisasi yang terlibat 
dalam kajian ini juga telah dihantar selepas dua minggu soal selidik diedarkan.

\section{Kaedah Analisis}

Berpandukan objektif kajian, fokus analisis yang telah dilaksanakan adalah tertumpu pada analisis statistik berbentuk deskriptif khususnya untuk bahagian I, II dan III. Pada bahagian IV dan V, kaedah analisis kandungan (content analysis) digunakan. Selain itu, pola persepsi organisasi terhadap prestasi pelajar UUM dan pengurusan praktikum juga diperhatikan mengikut jenis organisasi. Melalui pola ini, UIL berjaya mengenal pasti beberapa strategi baru bagi meningkatkan prestasi semasanya.

\section{HASIL KAJIAN DAN PERBINCANGAN}

\section{Profil Sampel}

Kajian ini melibatkan 438 organisasi yang terdiri daripada $45.1 \%$ organisasi milik swasta, $42.3 \%$ organisasi milik kerajaan, $8.0 \%$ organisasi berkaitan kerajaan, dan $4.6 \%$ organisasi bukan kerajaan (NGO). Pecahan organisasi mengikut kategori jenis operasi atau jenis industri adalah seperti berikut: $40.0 \%$ organisasi yang terlibat dalam kajian ini adalah organisasi berasaskan perkhidmatan, diikuti $13.2 \%$ organisasi yang menjalankan aktiviti perkhidmatan berasaskan kewangan dan insurans, $9.1 \%$ organisasi yang berasaskan perkhidmatan profesional, $8.7 \%$ organisasi yang dikategorikan sebagai perkilangan dan perdagangan manakala selebihnya iaitu sebanyak $29.0 \%$ organisasi adalah organisasi yang pelbagai jenis seperti pembinaan dan infrastruktur, perladangan dan pertanian, pengangkutan dan syarikat pelaburan. Keputusan ini menunjukkan bahawa fokus penempatan pelajar UUM adalah di sektor perkhidmatan yang umumnya banyak terlibat dengan aktiviti pengurusan, perancangan dan pentadbiran. Hal ini adalah bersesuaian dengan latar belakang UUM yang memberikan tumpuan terhadap bidang pengurusan dalam menawarkan program pengajian.

\section{Maklum Balas Terhadap Prestasi Pelajar}

Prestasi pelajar daripada sudut persepsi organisasi diukur dalam lima aspek yang mencakupi (i) pengetahuan asas, (ii) kemahiran 
komunikasi, (iii) kemahiran amali atau praktikal, (iv) kepemimpinan serta (iv) sikap dan disiplin diri. Perbincangan berkaitan maklum balas kelima-lima aspek ini dilakukan secara terperinci pada bahagian berikutnya.

\section{Pengetahuan Asas}

Aspek pengetahuan asas dalam kajian ini diukur berasaskan empat elemen, iaitu, (i) pengetahuan berkaitan bidang pengajian, (ii) pengetahuan yang bersangkutan dengan bidang tugas atau tanggungjawab, (iii) pengetahuan tentang organisasi pelajar menjalani praktikum, dan (iv) pengetahuan semasa. Jadual 1 membentangkan peratusan penilaian yang memberi skor prestasi yang diharapkan oleh UUM (iaitu skor 3 sehingga 5 daripada skala Likert 1 hingga 5 dengan skor 1 mewakili "sangat tidak memuaskan" dan skor 5 sebagai "cemerlang"). Keputusan dalam Jadual 1 menunjukkan bahawa pelajar yang sedang menjalani praktikum adalah berada pada tahap yang memuaskan dalam aspek pengetahuan asas.

Pelajar UUM didapati menguasai pengetahuan asas yang dinilai. Walau bagaimanapun, skor terendah yang direkodkan oleh sektor perkilangan dan perdagangan terhadap pengetahuan berkaitan organisasi $(89.5 \%)$ menggambarkan bahawa pelajar UUM kurang mempunyai pendedahan berkaitan dengan sektor berkenaan.

Jadual 1

Peratusan Penilaian Prestasi dengan Skor 3 hingga 5 bagi Komponen Pengetahuan Asas

Pengetahuan asas berkaitan

Jenis organisasi

$\begin{array}{cc}\text { Bidang } & \text { Tugas dan } \\ \text { pengajian } & \text { tanggungjawab }\end{array}$ Organisasi $\begin{gathered}\text { Isu } \\ \text { semasa }\end{gathered}$

\begin{tabular}{lrrrr}
\hline Perkhidmatan & 99.4 & 98.8 & 96.6 & 97.1 \\
Perkhidmatan kewangan dan & 100.0 & 100.0 & 93.1 & 98.3 \\
insurans & 100.0 & 97.5 & 100.0 & 92.5 \\
Perkhidmatan profesional & 97.4 & 97.4 & 89.5 & 94.7 \\
Perkilangan dan perdagangan & 99.2 & 99.2 & 97.6 & 97.6 \\
\hline
\end{tabular}




\section{Kemahiran Komunikasi}

Aspek komunikasi merupakan perantara utama proses penyampaian maklumat antara organisasi dan pekerja. Komunikasi yang tidak jelas boleh menyebabkan maklumat tidak dapat disampaikan daripada pemberi kepada penerima ataupun boleh disalahtafsirkan. Dalam menilai kemahiran komunikasi pelajar, dua aspek diperhatikan iaitu (i) komunikasi lisan (pertuturan) dan (ii) komunikasi bertulis. Kompetensi pelajar berkomunikasi secara lisan dan bertulis dinilai kemampuan dalam dua bahasa iaitu (i) Bahasa Malaysia yang merupakan bahasa kebangsaan Malaysia dan (ii) Bahasa Inggeris yang merupakan bahasa antarabangsa.

Jadual 2 memaparkan keputusan statistik berkaitan kebolehupayaan pelajar UUM berkomunikasi. Pelajar UUM didapati tidak menghadapi masalah untuk berkomunikasi dalam Bahasa Melayu tetapi wujud sedikit kekurangan untuk berkomunikasi dalam Bahasa Inggeris. Pada jadual tersebut juga, skor peratusan terendah direkodkan oleh perkhidmatan profesional (89.7\%), iaitu jauh lebih rendah berbanding organisasi lain.

\section{Jadual 2}

Peratusan Penilaian Prestasi dengan Skor 3 hingga 5 bagi Komponen Kemahiran Komunikasi

\begin{tabular}{lcccc}
\hline \multirow{2}{*}{ Jenis organisasi } & \multicolumn{4}{c}{ Kemahiran komunikasi } \\
\cline { 2 - 5 } & Bahasa Melayu & Bahasa Inggeris \\
\cline { 2 - 5 } & Lisan & Bertulis & Lisan & Bertulis \\
\hline Perkhidmatan & 100.0 & 100.0 & 93.7 & 91.9 \\
Perkhidmatan kewangan dan insurans & 100.0 & 100.0 & 94.8 & 94.8 \\
Perkhidmatan profesional & 100.0 & 100.0 & 89.7 & 87.2 \\
Perkilangan dan perdagangan & 100.0 & 100.0 & 94.7 & 94.7 \\
Lain-lain perkhidmatan & 100.0 & 98.4 & 95.2 & 95.2 \\
\hline
\end{tabular}

\section{Kemahiran Amali atau Praktikal}

Bersesuaian dengan latar belakang pendidikan dan program berbentuk kemahiran pengurusan yang ditawarkan di UUM, maka kemahiran amali yang dinilai melibatkan aspek-aspek tugasan yang berkaitan keupayaan penggunaan ICT, kebolehan dalam 
melaksanakan tugas yang diberikan, dan kebolehan menyelesaikan masalah berkaitan dengan tugasan yang diberikan.

Keputusan kajian ini seperti yang dibentangkan pada Jadual 3 menunjukkan bahawa semua organisasi terlibat bersetuju bahawa pelajar UUM berada pada tahap terbaik dalam penggunaan ICT. Dapatan ini mungkin disebabkan oleh kesan pendedahan penggunaan komputer dalam menyiapkan tugasan belajar termasuklah amalan penggunaan "Learning Care" di UUM. Kompetensi pelajar dalam melaksanakan tugas yang diberikan juga memuaskan tetapi terdapat sedikit penurunan skor peratusan dalam kemahiran menyelesaikan masalah berkaitan tugas yang diberi. Didapati juga, sektor perkilangan dan perdagangan merekodkan skor peratusan $(86.8 \%)$ paling rendah bagi kemahiran pelajar menyelesaikan masalah berkaitan tugas.

\section{Jadual 3}

Peratusan Penilaian Prestasi dengan Skor 3 hingga 5 bagi Komponen Kemahiran Amali

\begin{tabular}{lccc}
\hline & \multicolumn{3}{c}{ Kemahiran amali } \\
\cline { 2 - 4 } Jenis organisasi & $\begin{array}{c}\text { Penggunaan } \\
\text { ICT }\end{array}$ & $\begin{array}{c}\text { Melaksanakan } \\
\text { tugas diberi }\end{array}$ & $\begin{array}{c}\text { Menyelesaikan masalah } \\
\text { berkaitan tugas }\end{array}$ \\
\hline $\begin{array}{l}\text { Perkhidmatan } \\
\begin{array}{l}\text { Perkhidmatan kewangan } \\
\text { dan insurans }\end{array}\end{array}$ & 100.0 & 99.4 & 97.7 \\
$\begin{array}{l}\text { Perkhidmatan profesional } \\
\text { Perkilangan dan }\end{array}$ & 100.0 & 100.0 & 98.3 \\
perdagangan & 100.0 & 95.0 & 97.5 \\
Lain-lain perkhidmatan & 99.2 & 97.4 & 86.8 \\
\hline
\end{tabular}

\section{Kepemimpinan}

Aspek kepemimpinan yang diukur memperlihatkan bahawa pelajar praktikum berada pada tahap memuaskan secara keseluruhannya. Kualiti kepemimpinan dinilai daripada aspek kebolehan pelajar (i) membuat keputusan selaras dengan objektif atau perancangan tugasan, (ii) memimpin rakan-rakan sebaya yang lain, (iii) bekerjasama dalam kumpulan, (iv) amanah terhadap tugas yang diberikan, (v) menerima tanggungjawab dan (vi) mempamerkan hasil kualiti kerja yang baik. 
Jadual 4 menunjukkan bahawa pelajar dinilai dengan skor yang baik di semua organisasi tetapi skor agak rendah (89.5\% untuk membuat keputusan dan $89.2 \%$ untuk memimpin rakan sebaya) dalam sektor perkilangan dan perdagangan. Dapatan sebegini mungkin disebabkan oleh proses-proses membuat keputusan adalah lebih mencabar dan selalunya perlu melalui atau dilakukan oleh pegawai-pegawai atasan. Aspek kepemimpinan yang melibatkan amanah dan tanggungjawab merekodkan skor hampir sempurna.

\section{Jadual 4}

Peratusan Penilaian Prestasi dengan Skor 3 hingga 5 bagi Komponen Kepimpinan

\begin{tabular}{lcccccc}
\hline & \multicolumn{6}{c}{ Kepimpinan } \\
\cline { 2 - 7 } Jenis organisasi & $\begin{array}{c}\text { Membuat } \\
\text { keputusan }\end{array}$ & $\begin{array}{c}\text { Memimpin } \\
\text { rakan sebaya }\end{array}$ & $\begin{array}{c}\text { Kerjasama } \\
\text { dalam } \\
\text { kumpulan }\end{array}$ & Amanah & $\begin{array}{c}\text { Bertanggung } \\
\text { jawab }\end{array}$ & $\begin{array}{c}\text { Kualiti } \\
\text { kerja }\end{array}$ \\
\hline Perkhidmatan & 98.3 & 97.1 & 100.0 & 99.4 & 100.0 & 98.9 \\
$\begin{array}{l}\text { Perkhidmatan } \\
\text { kewangan dan } \\
\text { insurans }\end{array}$ & 98.3 & 100.0 & 100.0 & 100.0 & 100.0 & 100.0 \\
$\begin{array}{l}\text { Perkilangan dan } \\
\text { perdagangan }\end{array}$ & 89.5 & 89.2 & 100.0 & 100.0 & 100.0 & 97.3 \\
$\begin{array}{l}\text { Lain-lain } \\
\text { perkhidmatan }\end{array}$ & 97.6 & 96.7 & 99.2 & 100.0 & 100.0 & 99.2 \\
\hline
\end{tabular}

\section{Sikap dan Disiplin}

Sikap dan disiplin adalah kriteria penting yang sentiasa diutamakan oleh organisasi terhadap pekerjanya selain daripada mutu kerja. Dalam kajian ini, sikap dan disiplin pelajar diukur supaya keterampilan pelajar sebagai "duta kecil" universiti di organisasi dapat dikaji.

Sebanyak tujuh kriteria yang berkaitan dengan sikap dan disiplin dinilai iaitu, berkaitan dengan (i) kecenderungan pelajar untuk meningkatkan pengetahuan dan kemahiran, (ii) keupayaan pelajar menunjukkan komitmen yang tinggi dalam melaksanakan tugas atau kerja, (iii) keyakinan diri pelajar yang tinggi dalam melaksanakan tugas atau kerja, (iv) penampilan diri pelajar yang menarik dan sesuai, (v) mematuhi ketepatan masa, (vi) keupayaan pelajar menyempurnakan tugasan mengikut tempoh perancangan, dan (vii) tahap kesediaan pelajar menyumbangkan perkhidmatan jika diperlukan. 
Empat daripada tujuh kriteria yang diperhatikan menunjukkan kesamaaan penilaian bagi semua organisasi. Pelajar UUM didapati memiliki sikap dan disiplin yang sangat memuaskan dalam elemen penilaian (i), (iii), (iv) dan (vi). Manakala keputusan penilaian terhadap tiga elemen lagi adalah seperti pada Jadual 5. Secara keseluruhannya, pelajar praktikum mempunyai sikap dan disiplin yang baik di sepanjang tempoh latihan mereka.

\section{Jadual 5}

Peratusan Penilaian Prestasi dengan Skor 3 hingga 5 bagi Komponen Sikap dan Disiplin

\begin{tabular}{lccc}
\hline \multirow{2}{*}{ Jenis organisasi } & \multicolumn{3}{c}{ Sikap dan disiplin } \\
\cline { 2 - 4 } & $\begin{array}{c}\text { Komitmen } \\
\text { menjalankan tugas }\end{array}$ & $\begin{array}{c}\text { Ketepatan masa } \\
\text { menghadiri kerja }\end{array}$ & $\begin{array}{c}\text { Kesediaan } \\
\text { memberi bantuan }\end{array}$ \\
\hline $\begin{array}{l}\text { Perkhidmatan } \\
\begin{array}{l}\text { Perkhidmatan kewangan } \\
\text { dan insurans }\end{array}\end{array}$ & 98.9 & 98.9 & 100.0 \\
$\begin{array}{l}\text { Perkilangan dan } \\
\text { perdagangan }\end{array}$ & 100.0 & 100.0 & 100.0 \\
\begin{tabular}{l} 
Lain-lain perkhidmatan \\
\hline
\end{tabular} & 99.2 & 100.0 & 100.0 \\
\hline
\end{tabular}

Rumusan daripada dapatan kajian ini menunjukkan bahawa prestasi pelajar UUM adalah sangat memuaskan di kaca mata pelbagai organisasi yang dikaji. Prestasi pelajar yang terlibat di sektor perkhidmatan secara umumnya adalah lebih baik berbanding pelajar yang ditempatkan di sektor-sektor yang lain. Prestasi pelajar dalam sektor perkilangan dan perdagangan pula adalah yang paling lemah. Hal ini jelas dengan merujuk kepada carta radar pada Rajah 1 yang merumuskan skor purata bagi kelima-lima aspek penilaian prestasi pelajar oleh lima sektor organisasi yang diperhatikan. Carta ini mampu memberi petunjuk tentang nilai prestasi pelajar UUM dan kekuatan serta kelemahan pelajar dalam setiap elemen yang diperhatikan. Secara umumnya, prestasi pelajar dianggap sempurna sekiranya carta radar berbentuk heksagon menunjukkan kelima-lima elemen memperoleh skor cemerlang, iaitu 5. Prestasi pelajar boleh dianggap bermasalah sekiranya radar tidak berbentuk heksagon dengan skor rendah bagi satu-satu elemen. Sekiranya ini berlaku, maka tindakan penambahbaikan perlu diambil bagi memperbaiki kelemahan yang telah dikenal pasti. 


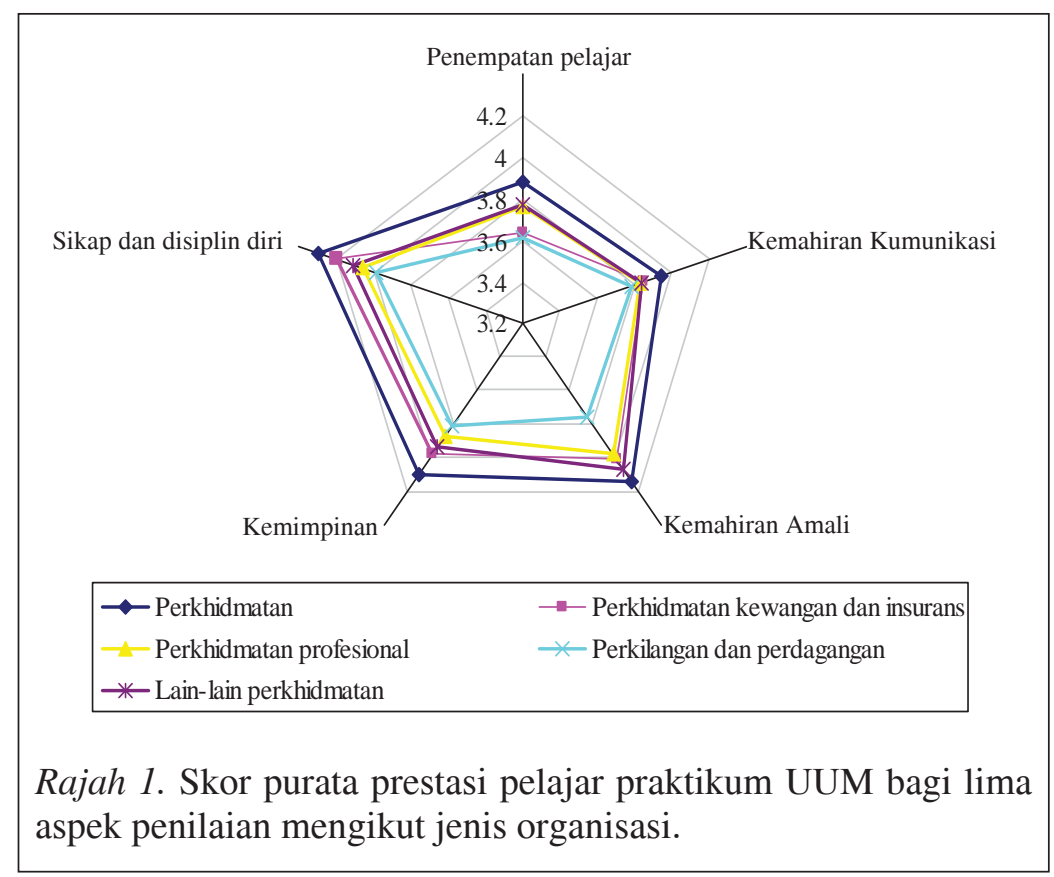

Berdasarkan Rajah 1, organisasi dari sektor perkhidmatan melaporkan bahawa pelajar UUM memiliki prestasi yang boleh dikategorikan sebagai baik bagi kesemua elemen yang diperhatikan terutamanya pada sikap dan disiplin diri. Walau bagaimanapun, kemahiran komunikasi dan pengetahuan asas perlu diberi perhatian kerana nilai min kedua-dua elemen ini hanya berada pada tahap memuaskan. Namun begitu, sektor perkilangan dan perdagangan menunjukkan skor min yang terendah dalam penilaian mereka terhadap prestasi pelajar UUM. Di samping itu, berdasarkan skor min, prestasi pelajar didapati hanya berada pada tahap memuaskan bagi tiga elemen, iaitu pengetahuan asas, kemahiran amali, dan kemahiran komunikasi. Hasil penilaian sebegini boleh dikaitkan dengan sistem amalan atau praktis di organisasi, terutamanya di sektor perkilangan, yang pada kelazimannya tidak selari dengan ilmu yang dipelajari di dewan kuliah. Justeru, pelajar kurang berupaya menangani permasalahan dalam tugasan yang diberikan tanpa pengalaman yang mencukupi. Selain itu, prestasi pelajar di sektor perkhidmatan kewangan dan insurans juga perlu diberi perhatian. Hal ini adalah kerana skor persepsi organisasi terhadap aspek pengetahuan asas dan kemahiran komunikasi pelajar UUM hanya pada tahap memuaskan sahaja. 


\section{Maklum Balas Terhadap Prestasi Pengurusan Praktikum}

Pengurusan program praktikum yang dikendalikan oleh UIL, Universiti Utara Malaysia adalah berpandukan MS ISO 9001:2000 yang diamalkan sejak tahun 2001 lagi. Berdasarkan piawaian ini, pengurusan praktikum adalah mengikut prosedur berikut: (i) penempatan pelajar: pelajar akan ditempatkan di organisasi yang telah dikenal pasti oleh Pusat Praktikum, (ii) penyeliaan pelajar: pelajar akan dilawat oleh pensyarah UUM yang dilantik dan (iii) penilaian pelajar: laporan akhir pelajar akan disemak oleh pensyarah dilantik untuk tujuan penggredan.

Sehubungan itu, hasil kajian ini mendapati bahawa skor min prestasi pengurusan program praktikum UUM berdasarkan pengamatan organisasi/ majikan adalah pada tahap memuaskan. Skor keseluruhan bagi setiap aktiviti yang terlibat dalam setiap prosedur pengurusan yang dinilai adalah seperti dalam Jadual 6 .

Jadual 6

Skor Umum Aktiviti Pengurusan Praktikum

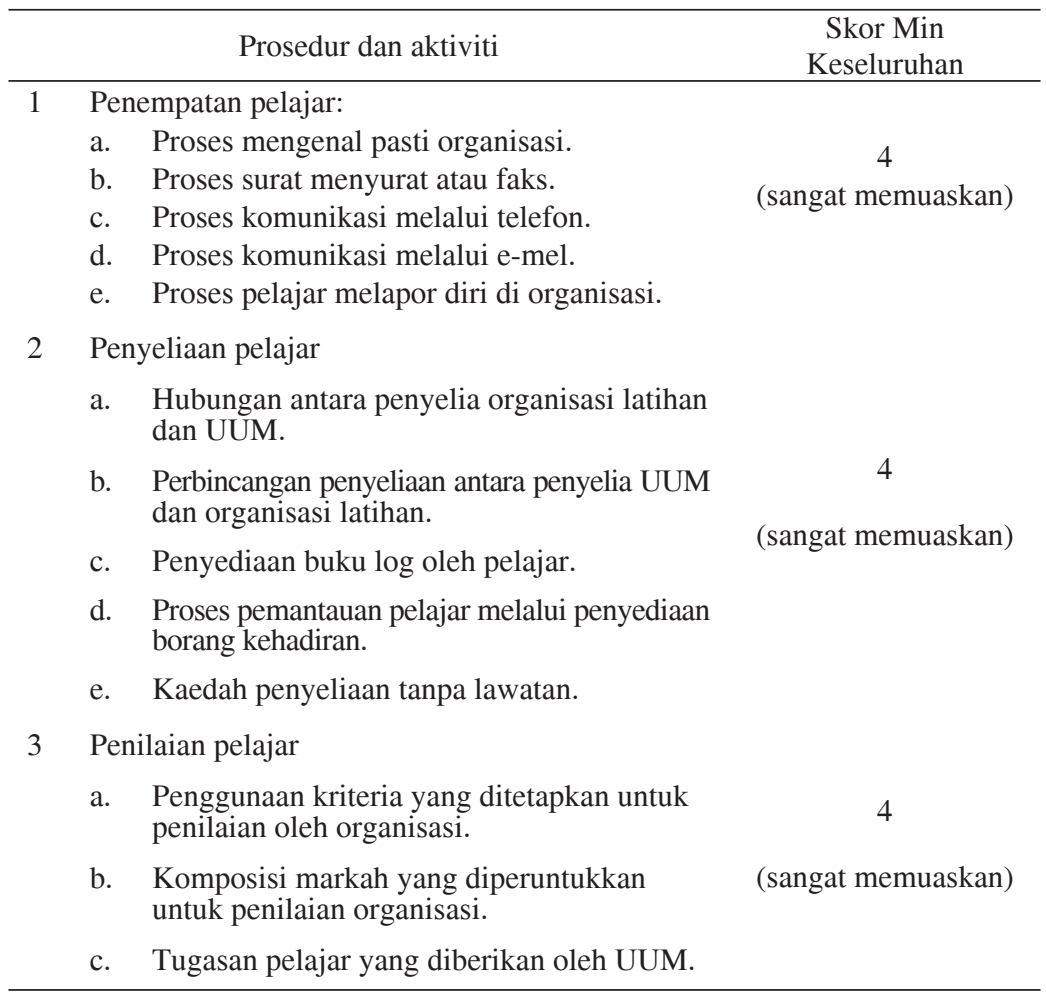


Analisis daripada segi perbandingan penilaian antara jenis organisasi terhadap ketiga-tiga aktiviti yang terlibat dalam pengurusan program praktikum dalam Rajah 2 menunjukkan bahawa skor min persepsi organisasi terhadap prestasi pengurusan program praktikum yang dikendalikan oleh UIL adalah berada pada tahap memuaskan bagi setiap jenis organisasi.

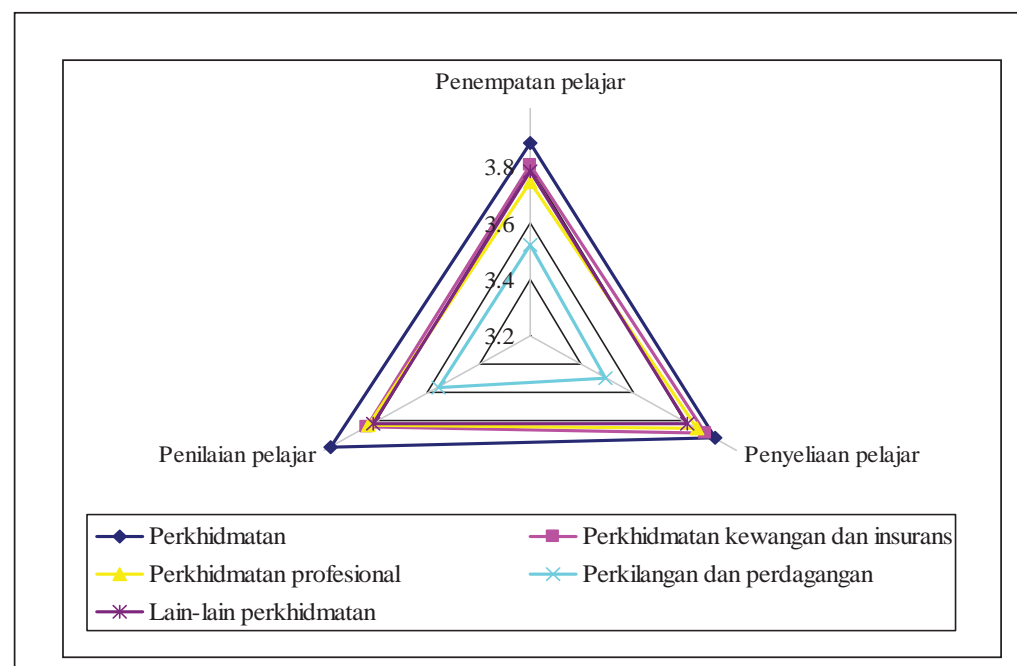

Rajah 2. Skor purata prestasi pengurusan program praktikum UUM bagi lima aspek penilaian mengikut jenis organisasi.

Berdasarkan keputusan dalam Rajah 2 juga, didapati bahawa sektor perkhidmatan menilai prestasi pengurusan praktikum di UUM adalah lebih tinggi daripada segi skor minnya berbanding dengan sektor-sektor yang lain. Manakala sektor perkilangan dan perdagangan pula mencatatkan skor min yang paling rendah terutamanya pada elemen penyeliaan pelajar. Sungguhpun begitu, secara umumnya tidak wujud perbezaan yang ketara antara sektor organisasi dalam penilaian prestasi pengurusan praktikum yang dilaksanakan oleh UIL.

\section{Perbandingan Prestasi Pelajar UUM dan Pelajar IPT lain di Malaysia}

Program praktikum merupakan satu program perkongsian bijak universiti-organisasi yang ditawarkan kepada hampir semua 
program di IPTA/ IPTS di Malaysia. Justeru, pihak organisasi biasanya menerima pelajar praktikum daripada pelbagai institusi pengajian tinggi. Kajian ini mendapati bahawa $78 \%$ organisasi menerima pelajar praktikum UUM turut sama menyediakan penempatan praktikum untuk pelajar dari IPTA atau IPTS yang lain, manakala $22 \%$ organisasi pula hanya menempatkan pelajar UUM sahaja untuk tujuan praktikum. Sebahagian besar sektor yang terlibat dalam kumpulan peratusan ini adalah dari sektor perkhidmatan yang berorientasikan kewangan dan insurans. Gambaran ini menunjukkan bahawa kebolehpasaran pelajar UUM adalah cerah di sektor tersebut. Keadaan ini mungkin juga disebabkan oleh perjanjian persefahaman (MoU) yang dilaksanakan oleh UUM dengan organisasi-organisasi berkaitan program praktikum.

Sehubungan itu, dalam kalangan 340 organisasi yang menerima pelajar praktikum daripada pelbagai IPTA atau IPTS, sebanyak 134 organisasi (39\%) memberi maklum balas berkaitan perbandingan prestasi antara pelajar praktikum UUM dan pelajar praktikum IPTA atau IPTS lain. Daripada kumpulan ini, 90\% mengkategorikan prestasi pelajar UUM adalah lebih baik atau setara dengan pelajar daripada IPTA atau IPTS lain. Baki sebanyak 206 organisasi (61\%) yang tidak memberi maklum balas pula melihat perbandingan sebagai tidak wajar dilakukan kerana pelajar melaksanakan tugas dan mempunyai latar belakang kemahiran yang berbeza.

Daripada aspek pengurusan praktikum pula, didapati wujud beberapa kelebihan dan kelemahan yang dikesan oleh organisasi pada proses penempatan pelajar praktikum yang dilaksanakan oleh UIL. Dalam pemerhatian ini, hanya 67 organisasi sahaja yang memberi maklum balas dan keputusannya adalah seperti pada Jadual 7. Lajur di hujung sebelah kanan Jadual 7 menunjukkan bilangan organisasi yang menyatakan kelebihan atau kelemahan UIL tersebut tetapi angka-angka ini tidak menggambarkan prestasi keseluruhan UIL. Sebaliknya, maklumat pada Jadual 7 wajar dijadikan panduan dalam UIL menentukan kepentingan (priority) untuk melaksanakan aktiviti penambahbaikan prestasinya pada masa hadapan. Sebagai contoh, sebanyak 12 organisasi menyatakan bahawa berlakunya ketidaksesuaian penempatan praktikum yang disebabkan program pengajian pelajar adalah berbeza dengan prospek kerja di organisasi. Maklumat ini boleh membantu UIL untuk menilai kembali proses penentuan penempatan yang dipraktikkan. Berkaitan dengan itu 
juga satu panduan praktikum perlu disediakan untuk membantu organisasi menilai kesesuaian memberi penempatan praktikum kepada pelajar UUM sebelum pengesahan penempatan diberikan.

\section{Jadual 7}

Kelebihan dan Kelemahan Proses Pengurusan Penempatan Praktikum

Bil Bilangan

\section{Kelebihan}

1. Pelajar ditempatkan bersesuaian dengan latar belakang organisasi. 67

2. Sistem pengurusan yang teratur, cekap dan sistematik.

3. Kerjasama PPR sepanjang proses penempatan pelajar.

4. Ada sistem penyeliaan bersama dan lawatan pensyarah ke organisasi. 5

5. Ada sistem penyeliaan pensyarah dan buku log.

6. Tiada risiko perpindahan pelajar ke organisasi lain.

7. PPR bertanggungjawab atas kebajikan pelajar semasa tempoh praktikum. 1

8. Cepat memberi maklum balas.

\section{Kekurangan}

1. Ketidaksesuaian program pengajian pelajar dan prospek kerja di organisasi. 12

2. Makluman berkaitan penempatan praktikum agak lewat diterima.

3. Kurang berkomunikasi dengan organisasi sepanjang tempoh 3

4. Pelajar tidak merasa seronok ditempatkan di organisasi bukan 1 pilihan mereka.

Pada keseluruhannya, kajian ini menunjukkan bahawa maklum balas tentang prestasi pengurusan pelajar untuk program praktikum adalah baik dan banyak menerima pujian organisasi. Hal ini mungkin dapat dikaitkan dengan cara pengurusan program praktikum UUM yang berkesan semenjak dimulakan pada tahun 1985. Pengurusan program praktikum telah diurustadbirkan oleh sebuah pusat khas yang bertanggungjawab sepenuhnya dalam menguruskan pelajarpelajarnya untuk menjalani praktikum. Pengurusan sebegini adalah berbeza dengan amalan universiti-universiti lain (kecuali Universiti Malaya) yang menggalakkan pelajar untuk berurusan sendiri mencari penempatan latihan mereka. Justeru, kesan daripada itu telah menimbulkan kebimbangan pihak organisasi tentang tindakan pelajar yang bertukar ke organisasi lain pada saat akhir disebabkan mereka telah menerima tawaran yang lebih lumayan. 
Walaupun begitu, penempatan yang dilakukan oleh UIL, UUM, tidak seratus peratus mampu memastikan bahawa pelajar ditempatkan di organisasi yang relevan dengan latar belakang program pengajian mereka. Proses penempatan pelajar secara manual yang dilakukan oleh staf UIL mungkin terdedah kepada kesilapan dan kurang kepekaan mereka terhadap perubahan yang berlaku di dalam sesebuah organisasi berkaitan. Tambahan pula, bilangan pelajar yang mendaftar untuk sesuatu sesi praktikum adalah ramai. Dianggarkan lebih kurang 5000 pelajar telah mendaftar untuk menjalani program praktikum pada setiap tahun. Oleh itu, inisiatif memperkenalkan penempatan pelajar praktikum secara atas talian adalah wajar dilaksanakan (Shahizan et al, 2006).

\section{RUMUSAN DAN CADANGAN}

Secara umumnya, hasil kajian ini menunjukkan bahawa prestasi pelajar UUM telah diamati oleh pihak organisasi berada pada tahap yang memuaskan. Walaupun begitu, pengetahuan asas dan kemahiran komunikasi dilihat sebagai aspek yang perlu dipertingkatkan penguasaannya dalam kalangan pelajar. Manakala itu, pengurusan praktikum yang dilaksanakan oleh UIL juga diamati oleh pihak organisasi berada pada paras prestasi yang memuaskan. Hal ini merupakan satu petunjuk bahawa organisasi berpuas hati dengan sistem pengurusan pelajar praktikum di UUM. Seterusnya daripada segi prestasi pelajar UUM berbanding dengan pelajar dari institusi pengajian tinggi yang lain pula, hasil kajian ini menggambarkan bahawa tidak menunjukkan perbezaan yang ketara dalam aspekaspek yang dinilai. Sehubungan itu, pihak organisasi turut memberi beberapa cadangan ke arah memperkasa dan menambah baik terhadap potensi diri pelajar untuk meningkatkan kebolehpasaran yang tinggi. Antara cadangan organisasi berkaitan dengan aspek pengetahuan dan kemahiran yang perlu diterapkan kepada pelajar UUM adalah:

i. Pengetahuan asas perakaunan.

ii. Pengetahuan analitik dan pemikiran kritis.

iii. Perakaunan syarikat.

iv. Perancangan aset (Property planning).

v. Pengurusan risiko.

vi. Undang-undang pengurusan kontrak.

vii. Pengurusan dan pentadbiran pejabat.

viii. Penguasaan berkomunikasi dalam Bahasa Inggeris

ix. Kemahiran interpersonal. 
Sehubungan itu, dengan dapatan kajian ini beberapa implikasi yang bernilai dapat dimanfaatkan terutamanya kepada pihak yang terlibat sama ada secara langsung atau tidak langsung dalam program latihan industri atau praktikum. Hasil kajian ini sedikit sebanyak dapat membekalkan input tentang aspek-aspek pengurusan program latihan industri/ praktikum untuk membantu IPTA/ IPTS dalam penggubalan program latihan industri/ praktikum. Di samping itu, maklum balas daripada industri/ organisasi tentang aspek pengurusan dan prestasi pelajar dalam praktikum juga boleh digunakan oleh IPTA/ IPTS untuk menghasilkan kurikulum praktikum yang lebih mantap.

Selain itu, dapatan kajian ini menggambarkan bahawa aspek kemahiran insaniah seperti kemahiran berkomunikasi dalam Bahasa Inggeris dan pengetahuan asas tentang bidang kerja di organisasi merupakan aspek-aspek yang mendapat skor rendah dari segi min pencapaian pelajar mengikut persepsi organisasi. Maklumat yang seumpama ini adalah penting untuk diketahui oleh pihak universiti dan kolej masing-masing supaya strategi-strategi tertentu dapat dirancang bagi meningkatkan kemahiran-kemahiran yang telah dikenal pasti. Hasil daripada usaha universiti dan kolej dalam mengatasi kelemahan-kelemahan pelajar sudah pasti membantu para pelajarnya menjadi lebih kompeten dan berkeyakinan.

Di samping itu, hasil kajian ini juga dapat menyumbang kepada pihak pengurusan universiti khususnya yang berkaitan dengan pengurusan latihan industri/ praktikum dalam proses merancang, melaksana, dan menilai program latihan industri/ praktikum. Berdasarkan dapatan kajian ini, memperlihatkan bahawa persepsi dan ekspektasi organisasi di organisasi swasta dan kerajaan adalah berbeza terhadap kemahiran yang dikuasai oleh para pelajar. Justeru, adalah menjadi tanggungjawab pihak universiti untuk mengatur program dan kursus yang bersesuaian kepada pelajarnya supaya dapat memenuhi kehendak dan keperluan organisasi, dan seterusnya kebolehpasaran dalam kalangan pelajarnya turut dipertingkatkan.

Di samping itu, kajian ini dapat membantu pelajar-pelajar IPTA yang akan menjalani praktikum, khususnya para pelajar UUM, untuk membuat persediaan yang secukupnya. Sebelum ini mereka mungkin mendapatkan pendedahan melalui sesi taklimat dan bengkel praktikum yang diadakan oleh pihak UIL dan fakulti masing-masing, tetapi dengan maklumat yang dibekalkan melalui kajian ini mereka sudah pasti dapat melihat dengan lebih jelas 
lagi tentang kelemahan yang diamati oleh organisasi terhadap para pelajar yang menjalankan praktikum. Maka, secara tidak langsung dapat memberi kesedaran kepada mereka bahawa hal itu akan menggagalkan seseorang pelajar memperoleh keputusan yang cemerlang dalam latihan industri serta turut menjejaskan imej universiti.

Kajian ini hanya memberi tumpuan kepada pelajar-pelajar UUM yang mengikuti program praktikum sesi A062 secara menyeluruh tanpa meneliti secara khusus mengikut perbezaan jantina, kelompok etnik, dan program pengajian masing-masing berkaitan dengan prestasi mereka semasa menjalani praktikum. Kajian ini juga hanya menggunakan soal selidik untuk mengukur aspek-aspek yang dikaji. Data tentang pengurusan program latihan industri/ praktikum dan prestasi pelajar diperoleh semata-mata berdasarkan tanggapan organisasi/ responden terhadap item-item yang dibekalkan dalam soal selidik. Oleh yang demikian, dalam responden memberi tanggapan, nilai dan pemahaman responden mungkin berbeza-beza. Hasilnya mungkin berlaku kurang ketepatan seperti yang dijelaskan oleh Isaac dan Michael (1984) bahawa "ia berkecenderungan untuk berubah, tidak boleh diduga, dan sensitif terhadap banyak faktor, iaitu, faktor dalaman dan luaran." (hal. 216).

Oleh itu, kajian lanjutan disyorkan menggunakan sampel yang lebih besar dengan mengambil kira organisasi-organisasi yang mengambil pelajar praktikum dalam beberapa sesi penempatan. Dengan menambah bilangan organisasi/responden dalam kajian akan dapat menghasilkan dapatan yang lebih reliable dan tepat tentang fenomena yang dikaji. Selain itu, mungkin juga wajar dalam kajian untuk masa hadapan turut mengkaji tentang persepsi penyelia-penyelia daripada universiti berkenaan tahap pengurusan program praktikum dan prestasi pelajar dalam menjalankan praktikum di industri/organisasi yang dipilih. Di samping itu, adalah disyorkan bahawa kajian pada masa hadapan perlu mengambil kira daripada segi perbezaan program pengajian yang diikuti oleh para pelajar. Oleh itu, pelbagai maklumat yang diperoleh kelak sudah pasti memberi gambaran yang lebih tepat untuk pihak pengurusan berkenaan membuat penambahbaikan dalam pengurusan praktikum.

Di samsping itu, kajian yang melibatkan persepsi adalah sukar diukur secara objektif. Justeru, di samping menjalankan kajian yang berbentuk kuantitatif, pendekatan kualitatif juga disyorkan untuk diterapkan bersama dalam kajian-kajian yang berkaitan pada masa hadapan. Usaha untuk menghubungkan data kuantitatif 
dan kualitatif merupakan satu percubaan untuk mendapatkan pemahaman sesuatu perspektif yang lebih luas dan mendalam ke atas fenomena yang dikaji (Floyd, 1999). Sehubungan itu, memilih cara mengadakan temu bual dengan organisasi-organisasi tentang aspek-aspek pengurusan program praktikum dan prestasi pelajar merupakan kaedah yang lebih bersifat objektif dan berupaya untuk mengumpulkan maklumat yang lebih terperinci dan mendalam.

Kajian ini mencadangkan supaya kajian-kajian pada masa akan datang dapat dikendalikan dengan mengambil kira cadangan dan batasan yang diutarakan. Kajian yang diusahakan ini adalah sebagai landasan untuk menggerakkan kajian-kajian lanjutan yang lebih berkesan, di samping memberi sumbangan dalam cara yang tersendiri. Justeru, diharapkan kemunculan pengkaji-pengkaji lain yang berminat dalam bidang yang sama untuk meneruskan kajian jenis ini dari semasa ke semasa supaya hasilnya kelak dapat memberi sumbangan yang bernilai kepada disiplin pengurusan khususnya dalam bidang pengurusan latihan industri/ praktikum di institusiinstitusi pengajian tinggi di negara ini.

\section{RUJUKAN}

Abdul Razak Abd Manaf \& Ahmad Shukri Abdul Hamid. (2002). Tinjauan terhadap permasalahan dan penilaian ke atas komponen latihan praktikum I program pengurusan kerja sosial. Laporan Penyelidikan. Sekolah Pembangunan Sosial, Universiti Utara Malaysia.

Almahdi Mohammad Almahdi Ahmed. (2006). Identifying student and organization matching pattern using data mining technique for practicum placement (Unpublished master's thesis). Universiti Utara Malaysia.

Barney, D., \& Pleban, F. (2006). Pre-service physical education teacher's perceptions of teaching before and after a semester long elementary physical education practicum experience. Physical Educator, 63(1), 46-52.

Basri Rashid (2001). Practical training from students' perspective: Problems during industrial placement. Paper presented at The First Hospitality and Tourism Educators National Conference. Park Plaza Hotel, Kuala Lumpur.

Beard, D. F. (2007). Assessment of internship experiences and accounting core competencies. Accounting Education: An International Journal, 16(2), 207-220. 
Beck, C., \& Kosnik, C. (2002). Components of a good practicum placement: Student teacher perceptions. Teacher Education Quarterly, 29(2), 81-97.

Doering, A., Johnson, M., \& Dexter, S. (2003). Using asynchronous discussion to support pre-service teachers' practicum experiences. TechTrends, 47(1), 52-55.

Dras, D. D.V., \& Miller, K.M. (2002). Learning outside the classroom: The undergraduate gerontology internship. Educational Gerontology, 28, 881-894.

Ferguson, G. (1991). Developing a curriculum for engineering graduate of today and tomorrow. Industrial Engineering, 23 (11), 78-90.

Floyd, M. F. (1999). Race, ethnicity and use of the national park system. Social Science Research Review, 1(2), 1-24.

Gardner, H. (1999). The discipline mind: What all students should understand. New York: Simon \& Schuster.

Girard, D. E., Hickam, D. H., Gordon, G. H., \& Robison, R. O. (1991). A perspective study of internal medicine residents' emotions and attitudes throughout their training. Academic Medicine, 66, 111-114.

Graf, N. M., \& Stebnicki, M. A. (2002). Using e-mail for clinical supervision in practicum: A qualitative analysis. Journal of Rehabilitation, 68(3), 41-49.

Griffith, C. H., \& Wilson, J. F. (2003). The loss of idealism throughout internship. Evaluation \& The Health Professions, 26(4), 415-426.

Henry, J. S., Rehwaldt, S. S., \& Vineyard, G. M. (2001). Congruency between student interns and worksite supervisors regarding critical elements of an intership experience. Information Technology, Learning, and Performance Journal, 19(1), 31-41.

Isaac, S., \& Micheal, W. B. (1984). Handbook in research and evaluation (4th ed). San Diego, California: EdiTs Pubblishers.

Ismail Mat \& Akmal Ilham. (2006, 15 November). Latihan amali universiti awam dilanjut 6 bulan. Berita Harian, m.s. 6 .

Kantha Kumar Ramasamy. (1997, April). Kajian persepsi guru pelatih mengenai kualiti dan keberkesanan bimbingan praktikum I Kursus Perguruan Asas Institut Perguruan Darul Aman. Kertas kerja dibentangkan dalam Seminar Penyelidikan Pendidikan di Bahagian Pendidikan Guru.

Lee, K. (2001, Jun). Practical, practicum and industrial placement: Expectations vs reality. Paper presented at The First 
Hospitality and Tourism Educators National Conference, Park Plaza Hotel, Kuala Lumpur.

Kok, R. M. (2000). Outside the box: Creating your own internship opportunities. Journal of Hospitality and Tourism Education, 12(3), 21-23.

Lawrence, S.S. (1991). Tomorrow's professional administrater, SRA Journal, 23(3), 110-121.

Lloyd, S. \& Bristol, S. (2006). Modeling mentorship and collaboration for BSN and MSN students in a community clinical practicum. Journal of Nursing Education, 45(4), 129-131.

Mihail, D. M. (2006). Internships at Greek universities: An exploratory study. Journal of Workplace Learning, 18 (1), 26-41.

Mohammad Hasnan Hassan \& Ang Chooi Leng. (2002). Keberkesanan kurikulum program sarjana muda sains pemutusan UUM-Penilaian lepas latihan praktikum. Laporan Penyelidikan, Sekolah Sains Kuantitatif, Universiti Utara Malaysia.

Mohd Noor Omar. (2006, 9 Januari). Latihan Industri jalin toleransi agama. Berita Harian, m.s. 13.

Mohd. Salleh Din, Norehan Abdullah, Mohd Fo'ad Sakdan, Shafee Saad, Azlina Murad Sani, Mohd. Basir Saud \& Kamran Sa'yan (1995). Persepsi majikan terhadap siswazah UUM 1985-1994. Laporan Penyelidikan. Universiti Utara Malaysia.

Murray-Harvey, R. (2001). How teacher education students cope with practicum concerns. The Teacher Education, 37(2), 117132.

Mustapa Mahamed (2007). Majlis Perundingan Akademia - Industri (APAI). Putrajaya.

Nash. T. (1992). The school gap. Director, 45(11), 45-52.

Oven, A. (2004). Using peer coaching and action research to structure the practicum concerns. The Teacher Education, $37(2), 117-132$.

Panos, P.T., Roby, J. L., Panos, A., Matheson, K. W., \& Cox, S. E. (2002). Ethical issues concerning the use of video conferencing to supervise international social work field practicum students. Journal of Social Work Education, 38(3), 421-437.

Pusat Praktikum (2005). Laporan prestasi pelajar praktikum UUM oleh penyelia organisasi. Sintok: Universiti Utara Malaysia.

Pusat Praktikum. (2005). Buku panduan praktikum. Universiti Utara Malaysia. 
Rosnita Binti Ahmad. (2005). Menilai persepsi majikan terhadap pelajar UUM yang menjalani latihan praktikum sesi 2004. Laporan Penyelidikan. Fakulti Pengurusan Awam dan Undang-Undang, Universiti Utara Malaysia.

Seigler, I. C., Gentry, W. D., \& Edwards, C. D. (1979). Training in geropsychology: A survey of graduate and internship training programs. Professional Psychology, 10(3), 390-395.

Sekaran, U. (2003). Research methods for business: A skill building approach (4th ed.). New York: John Wiley \& Sons. Inc.

Shahizan Hassan, Mohd Azlan Yahya, Abdul Razak Chik, \& Wan Husin Wan Ishak. (2006). Online student placement system (OPSP). Laporan Penyelidikan, Pusat Praktikum, Universiti Utara Malaysia.

Tyssen, R., Vaglum, P., Gronvold, N. T., \& Ekeberg, O. (2005). The relative importance of individual and organizational factors for the prevention of job stress during internship: A nationwide and prospective study. Medical Teacher, 27(8), 726-732.

Weinberg, R. B. (1986). The pre-doctoral psychology internship program at The University of South Florida/Florida Mental Institute. Professional Practice of Psychology, 7, 95-101.

Zhao, J., \& Harris, K. J. (2004). Industry internships: Feedback from participating faculty and industry executives. International Journal of Contemporary Hospitality Management, 16(2), 429-436. 